\title{
Inwentarz kościoła Świętego Ducha w Łęcznej z 1834 roku
}

ABstrakt: Dzieje fundacji prepozytury Świętego Ducha w Łęcznej nie są do końca rozpoznane. Nieznany jest także dokładny czas powstania kościoła szpitalnego. Historycy datują te wydarzenia w szerokim przedziale czasowym od 1540 r. do początku II dekady XVII w. Podobnie jak w innych miastach, łęczyński kościół szpitalny usytuowany był na przedmieściu, a znajdujący się przy nim przytułek służył chorym i ubogim mieszkańcom. Kościół był drewniany, stąd często dotykały go klęski pożaru. Na początku lat 30. XIX w. świątynia była w złym stanie technicznym, dlatego rozebrano ją pomiędzy wrześniem $1834 \mathrm{r}$. a kwietniem $1836 \mathrm{r}$.

Artykuł zawiera edycję inwentarza kościoła Świętego Ducha w Łęcznej z 1834 r.

SŁOWA KLUczowe: Łęczna, kościół Świętego Ducha, szpitalnictwo, inwentarz fundi instructi.

Kościół pw. Świętego Ducha w Łęcznej był drugą w kolejności powstania świątynią wyznania rzymskokatolickiego w mieście. Był to typowy miejski kościół szpitalny, przy którym działał przytułek dla ubogich i chorych. Świątynia z powodu złego stanu została rozebrana po 1834 r., zatem publikowany inwentarz przynosi informacje o ostatniej fazie jej istnienia w Łęcznej.

Dysponujemy dość obfitą bazą źródłową, umożliwiającą odtworzenie dziejów kościoła świętoduskiego. Składają się na nią informacje zawarte w wizytacjach parafii pw. św. Marii Magdaleny w Łęcznej, inwentarze kościoła i szpitala 
oraz zapiski, znajdujące się w księgach miejskich ${ }^{1}$. Ponadto położenie kościoła i obiektów z nim związanych oddają plany miejskie oraz plany obiektów kościelnych ${ }^{2}$. Bogata jest już także literatura poświęcona kościołowi szpitalnemu, a szczególny jej rozwój przypada na lata dwutysięczne ${ }^{3}$.

Zachowane źródła nie dają jednoznacznej odpowiedzi na pytanie o czas powstania prepozytury świętoduskiej, kościoła szpitalnego i szpitala w Łęcznej. W tej sprawie zarysowały się dwa stanowiska, w ramach których badacze datują te fakty albo na rok $1540^{4}$, albo na lata $1612-1613^{5}$. Podstawę tych rozbieżności stanowi znany z przekazów XVII- i XVIII-wiecznych zapis półłanka na rzecz kościoła szpitalnego, dokonany przez Annę Spiczyńską w 1540 r., $\mathrm{z}$ drugiej zaś strony informacje $\mathrm{z}$ wizytacji parafialnych z XVII w. o fundacji prepozytury szpitalnej przez łęczyńskiego proboszcza Stanisława Pierlewskiego (Pierlejewskiego). Rozstrzygnięcie kwestii początków szpitalnictwa w Łęcznej po części utrudnia niewyjaśniona sprawa umiejscowienia kościoła parafialnego i świętoduskiego na początku XVII w., związana z szeroko dyskutowaną

1 Zestawienie literatury i źródeł do zagadnienia zob.: Z. Góralski, Szpitale na Lubelszczyźnie w okresie przedrozbiorowym, cz. II, oprac. D. Wójcik-Góralska, Lublin 1999, s. 71-75; J. Chachaj, Szpitale przy świątyniach łacińskich $w$ Łęcznej w okresie przedrozbiorowym, „Merkuriusz Łęczyński”, nr 22, 2009, s. 2-8; R. Jop, Zmiany w przestrzeni miejsc sakralnych w Łęcznej w XVIXVIII wieku - kościót św. Marii Magdaleny i Świętego Ducha, [w:] Studia z dziejów parafii pw. św. Marii Magdaleny w Łęcznej, red. R. Jop, Łęczna 2010, s. 89-100.

2 Archiwum Państwowe w Lublinie (dalej: APL), Zbiór planów różnych urzędów, sygn. 267, Plan regulacyjny miasta Łęczny; APL, Komisja Województwa Lubelskiego i Rząd Gubernialny Lubelski, Wydział Administracyjny (dalej: KWLRGL, WA), sygn. 265, Acta specyjalia tyczace się Łęczny, kościoła i szpitala (dalej jako: Akta specyjalia).

3 J. T. Frazik, Łęczna. Rozwój i przemiany planistyczne miasta, „Zeszyty Naukowe Politechniki Krakowskiej”, nr 1: Architektura, 1956, s. 56; Z. Góralski, Szpitale na Lubelszczyźnie $w$ okresie przedrozbiorowym, Warszawa 1982; R. Szczygieł, Powstanie miasta Łęcznej i jego rozwój do końca XVI w., [w:] Łęczna. Studia z dziejów miasta, red. E. Horoch, Łęczna 1989, passim; Z. Góralski, Szpitale na Lubelszczyźnie, cz. II, s. 71-75; J. Łosowski, Urzędnicy miejscy, cechowi, braccy i szpitalni Łęcznej do roku 1810, Łęczna 2004, s. 29-34; P. Winiarski, Prepozytura Świętego Ducha w Łęcznej, „,Merkuriusz Łęczyński”, nr 17, 2004, s. 9-12; J. Chachaj, op. cit; R. Jop, Kościót i szpital Świętego Ducha w Łęcznej w wizytacjach z XVIII i XIX wieku, „Merkuriusz Łęczyński”, nr 23, 2010, s. 4-9; tegoż, Zmiany w przestrzeni, s. 89-100; tegoż, ,Jarmark w Łęcznej” Jana Piotra Norblina a łęczyński kościót pw. Świętego Ducha, [w:] Scientia nihil est quam veritas imago. Studia ofiarowane Profesorowi Ryszardowi Szczygłowi w siedemdziesięciolecie urodzin, red. A. Sochacka, P. Jusiak, Lublin 2014, s. 1153-1165; M. Bogusz, Miasto Łęczna w czasach Królestwa Polskiego (1815-1866), Łęczna 2014, s. 197-205.

4 J. T. Frazik, op. cit., s. 53; Z. Góralski, Szpitale na Lubelszczyźnie, s. 95; R. Szczygieł, op. cit., s. 38, 53; J. Łosowski, op. cit., s. 30.

5 J. Chachaj, op. cit., s. 4-5; R. Jop, Zmiany w przestrzeni, s. 91, 94-96. 
w literaturze przedmiotu tezą Józefa Frazika o relokacji obydwu świątyń. W II połowie XVII, w XVIII i pierwszej tercji XIX w. kościół Świętego Ducha i szpital znajdowały się na przedmieściu łęczyńskim, przy czym źródła nie informują, o które z nich chodziło. Biorąc pod uwagę położenie obiektu w XIX w. można przyjąć, że było to przedmieście na południe od miasta, czyli teren, na którym w latach 60. XVIII w. założono nowy rynek (Rynek I), miejsce słynnych jarmarków łęczyńskich. Wątpliwości może jednak budzić umiejscowienie kościoła na Rynku I w obliczu tego, że w 2013 r. w jego wschodniej części odkryto liczne pochówki, świadczące o istnieniu w tym miejscu cmentarza ${ }^{6}$, a w II połowie XVIII w. świątynia zajmowała zachodnią część placu, umiejscowioną za budynkiem ratusza miejskiego (dzisiaj Urząd Stanu Cywilnego w Łęcznej)7. Warto także dodać, że uznawana przez wiele lat teza jakoby kościół Świętego Ducha został uwieczniony na znanym rysunku Jana Piotra Norblina, została w 2014 r. obalona ${ }^{8}$.

Istnienie kościoła szpitalnego pw. Świętego Ducha w Łęcznej należy w związku z powyższym datować najszerzej od początku lat 40. XVI w. do połowy lat 30. XIX stulecia, chociaż niewykluczone, że momentem przełomowym w powstaniu prepozytury szpitalnej były lata 1612-1613. Okoliczności jego rozbiórki nie znamy. Z kwietnia 1836 r. pochodzą dwa dokumenty wystawione przez Bank Polski, będące dowodem złożonego depozytu pieniężnego ze sprzedaży materiałów z rozebranego kościoła świętoduskiego ${ }^{9}$. Do rozbiórki musiało zatem dojść pomiędzy wrześniem $1834 \mathrm{r}$. i kwietniem $1836 \mathrm{r}^{10}$

Kościół od początku swojego istnienia był budowlą drewnianą, ale posiadającą murowaną zakrystię, odnotowaną $\mathrm{w}$ tej formie po raz ostatni w wizytacji z $1748 \mathrm{r}^{11}$ Budulec świątyni spowodował, że często płonęła, szczególnie w XVIII w. podczas nękających Łęczną pożarów. Jeden z nich zniszczył kościół

${ }^{6}$ J. Tkaczyk, Zaskakujące odkrycia archeologiczne pod Rynkiem I w Łęcznej - badania wykopaliskowe cmentarza świętoduskiego, ,,Merkuriusz Łęczyński”, nr 26, 2013, s. 2-8.

7 Na to wskazuje plan Rynku I z 1857 i opis do niego w aktach dzierżawy placu kościelnego przez Ludwika Grabowskiego: KWLRGL, WA, sygn. 828, s. nlb. Zob. także: R. Jop, „Jarmark w Łęcznej", s. 1160-1161.

8 Ibidem, s. 1153-1165.

9 Acta specyjalia, k. 134, 135.

10 Por. M. Bogusz, Miasto Łęczna, s. 198.

11 Archiwum Archidiecezjalne w Lublinie, Konsystorz Generalny Lubelski, Rep. 60 A I, sygn. 99 (dalej: Wizytacja 1675), k. 93; ibidem, Rep. 60 A, sygn. 101 (dalej: Wizytacja 1739), k. 105; ibidem, Rep. 60 A, sygn. 103, k. 141 (dalej: Wizytacja 1748). 
szpitalny doszczętnie na początku XVIII stulecia. Nowy wystawiono w $1715 \mathrm{r}^{12}$ Podczas pożaru miasta w 1746 r. spalił się dach świątyni, ale jej zrąb ocalał ${ }^{13}$, nie spłonął także podczas pożaru w 1827 r. ${ }^{14}$ Stale jednak kościół był w złym stanie technicznym i pomimo podejmowanych prób jego restauracji chylił się ku upadkowi ${ }^{15}$. Ten stan budowli dokumentuje inwentarz z $1834 \mathrm{r}$.

Geneza prezentowanego inwentarza jest związana ze zmianami, jakie zaszły w zarządzie nad kościołem świętoduskim. Jak poinformował Komisję Województwa Lubelskiego pismem z dnia 23 IX 1834 r. Konsystorz Generalny Lubelski, 22 VIII tego roku zmarł kapelan Świętego Ducha, ksiądz Franciszek Brzozowski. Na nowego administratora powołano ówczesnego proboszcza parafii pw. św. Marii Magdaleny, księdza Maksymiliana Wrześniewskiego. Jednocześnie zobowiązano dziekana chełmskiego Jana Ewangelistę Dymowskiego do sporządzenia inwentarza fundi instructi kościoła i funduszu szpitalnego ${ }^{16}$. Komisja powołana do jego spisania w osobach dziekana Dymowskiego, burmistrza Łęcznej Adama Schybille, dwóch członków dozoru kościelnego: Szymona Wójcickiego i Feliksa Kowalskiego oraz dwóch rzeczoznawców (taxator): Pawła Sierpińskiego i Augustyna Nokczyńskiego, zebrała się w Łęcznej 27 IX 1834 r. Dokonano wizji lokalnej, opisano kościół i budynki należące do prepozytury, oszacowano dochody oraz wydatki i prawdopodobnie w kolejnych dniach przygotowano czystopis inwentarza, który został wysłany Komisji Województwa Lubelskiego 26 XI 1834 r. $^{17}$

W dokumencie zostały opisane zabudowania należące do prepozytury świętoduskiej oraz dochody i wydatki kościoła. Inwentarz, biorąc pod uwagę nieruchomości, uzupełnia, a nawet można powiedzieć, zamyka całą grupę akt, w których odnotowano wygląd kościoła szpitalnego i sam szpital. Składają się na nie przede wszystkim wizytacje parafii łęczyńskiej z XVII i XVIII w. Cztery z nich, pochodzące $\mathrm{z}$ lat 1780,1800, 1805 i 1830, znajdowały się w archiwum świętoduskiego kościoła ${ }^{18}$, ale nie zachowały się do dzisiaj. Podobnie jak żaden z ośmiu

\footnotetext{
${ }_{12}$ Ibidem. Archiwum Archidiecezjalne w Lublinie, Konsystorz Generalny Lubelski, Rep. 60 A, sygn. 104, s. 565 .

${ }_{13}$ Wizytacja 1748, k. 141.

${ }^{14}$ KWLRGL, WA, sygn. 828, s. nlb.

15 R. Jop, Zmiany w przestrzeni, s. 99-100.

16 Acta specyjalia, k. 74.

17 Ibidem, k. 80.

${ }^{18}$ Acta specyjalia, k. 86v.
} 
wykazanych dokumentów z zapisami na rzecz kościoła ${ }^{19}$, jeśli oczywiście pod tym punktem inwentarza kryją się ich oryginały lub wypisy z ksiąg miejskich, grodzkich itp. Spośród innych obiektów, opisanych w inwentarzu, zwraca uwagę całkiem pokaźna biblioteka obejmująca 22 tytuły w 37 woluminach ${ }^{20}$.

Inwentarz kościoła Świętego Ducha w Łęcznej przechowywany jest obecnie w Archiwum Państwowym w Lublinie, w jednostce o sygnaturze 265 Acta specyjalia tyczace się Łęczny, kościoła i szpitala, należącej do zespołu Komisja Województwa Lubelskiego i Rząd Gubernialny Lubelski, a w jego ramach do serii Wydział Administracyjny. Został spisany na sześciu kartach. Ich numeracja jest współczesna. Inwentarz ma w przeważającej części formę tabelaryczną. Zastosowano ją do wyszczególnienia paramentów kościelnych, szat liturgicznych, mebli itd. oraz w zapisach dotyczących majątku kościoła, jego dochodów i wydatków. Natomiast przedstawienie samej świątyni i zabudowań należących do prepozytury ma charakter opisowy. Dokument kończą podpisy członków komisji inwentaryzującej oraz pieczęcie tuszowe: miasta Łęczna, dziekana Dymowskiego oraz wójta gminy Łęczna Onufrego Popiela.

Inwentarz został wydany z zastosowaniem instrukcji wydawniczej dla źródeł XIX-wiecznych autorstwa Ireneusza Ihnatowicza ${ }^{21}$. Ze względu jednak na dość skomplikowaną formę tabeli w inwentarzu, w edycji zrezygnowano z niej, pozostawiając jedynie niektóre tytuły kolumn w celu orientacji w zastosowanych miernikach.

\section{Summary}

\section{The Inventory of the Holy Spirit Church in Łęczna of 1834}

The history of the Holy Spirit provostry foundation in Łęczna has not yet been fully investigated. The exact date of the establishment of the hospital church in Łęczna is also unknown. Historians date these events to a broad time bracket from 1540 to the beginnings of the second decades of the 17th century. Like in other towns, the Łęczna hospital church was situated on the outskirts, and the

\footnotetext{
19 Ibidem, k. 86-86v.

${ }^{20}$ Ibidem, k. 83. Por. księgozbiór kościoła parafialnego w Łęcznej: T. Moskal, Biblioteka parafialna w Łęcznej w okresie przedrozbiorowym, [w:] Studia z dziejów parafii, s. 115-120.

${ }^{21}$ I. Ihnatowicz, Projekt instrukcji wydawniczej dla źródeł historycznych XIX i początku XX wieku, [w:] „Studia Źródłoznawcze”, t. 7, 1962, s. 99-124.
} 
adjacent shelter served the sick and poor inhabitants. The church was wooden, which is why it was frequently hit by conflagrations. In the early 1830s the church was in poor technical condition, therefore why it was demolished between September 1834 and April 1836.

The article contains the edition of the 1834 inventory of the Holy Spirit church in Łęczna.

KEYWORDS: Łęczna, Holy Spirit church, hospitals, inventory fundi instructi. 


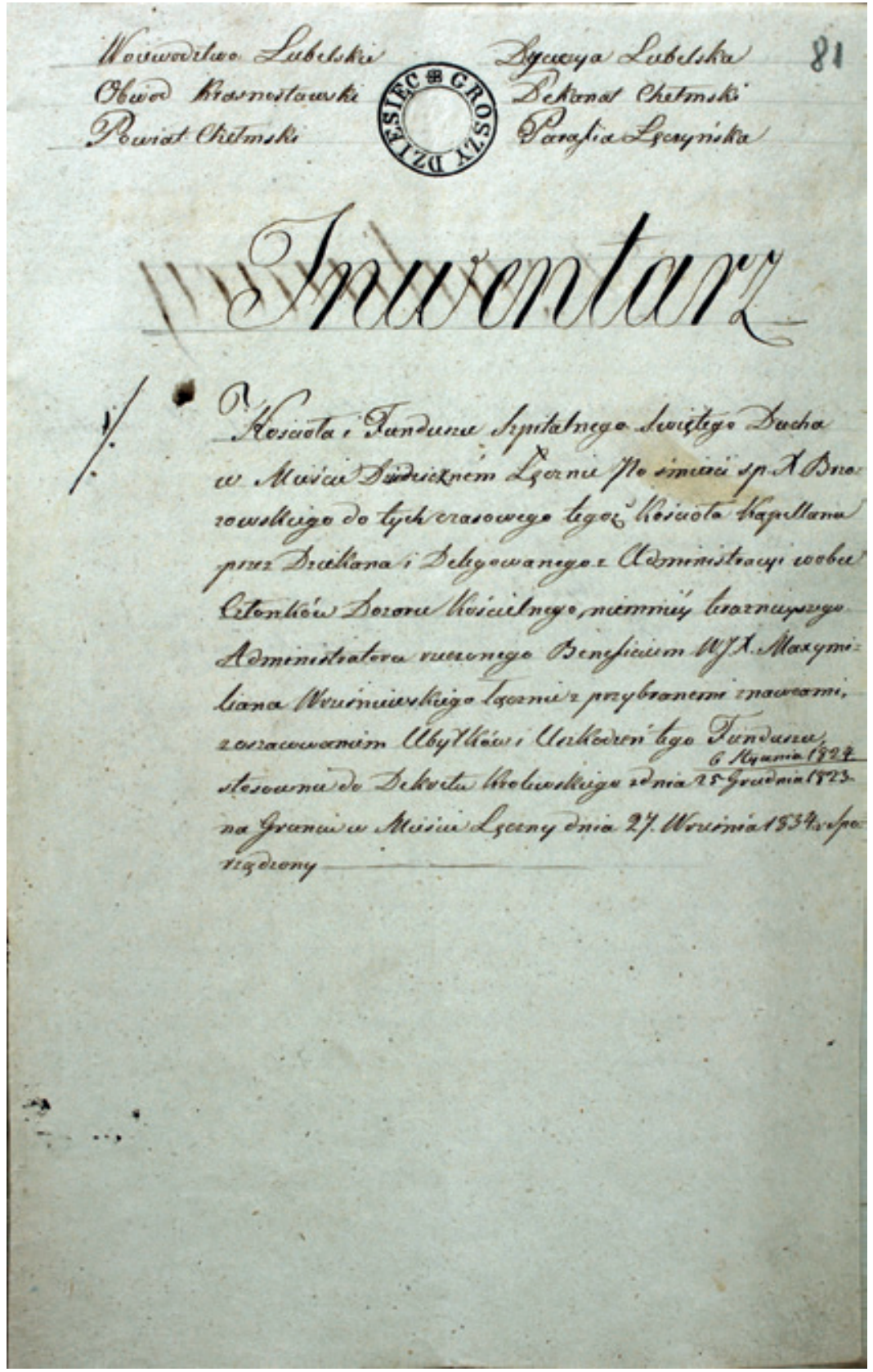

Il. 1. Strona tytułowa inwentarza kościoła szpitalnego pw. Świętego Ducha w Łęcznej, 1834 r. 


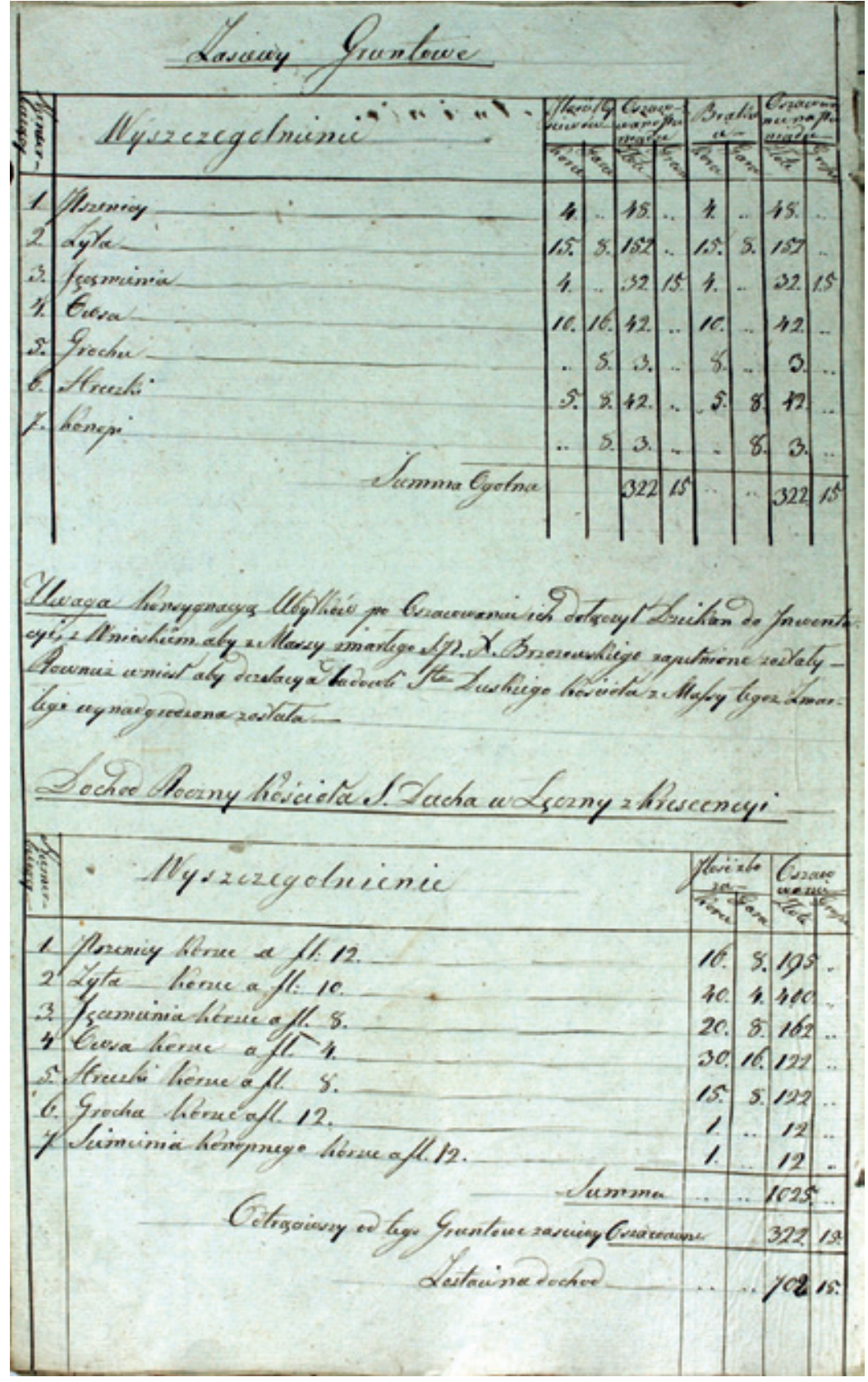

Il. 2. Inwentarz kościoła pw. Świętego Ducha w Łęcznej. Wykaz dochodów z zasiewów gruntowych, $1834 \mathrm{r}$. 


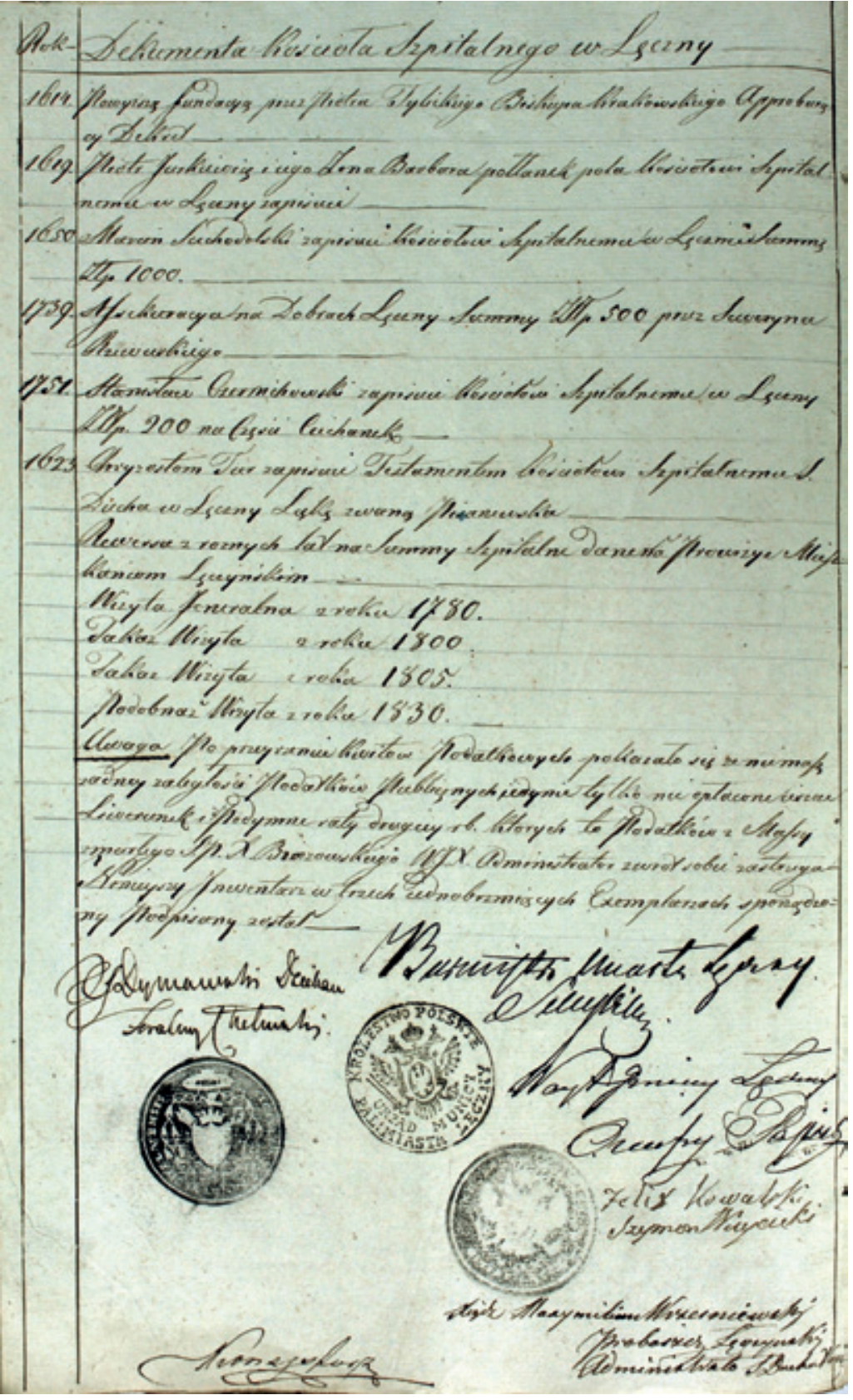

Il. 3. Ostatnia strona inwentarza z pieczątkami instytucji miejskich i kościelnych, $1834 \mathrm{r}$. 


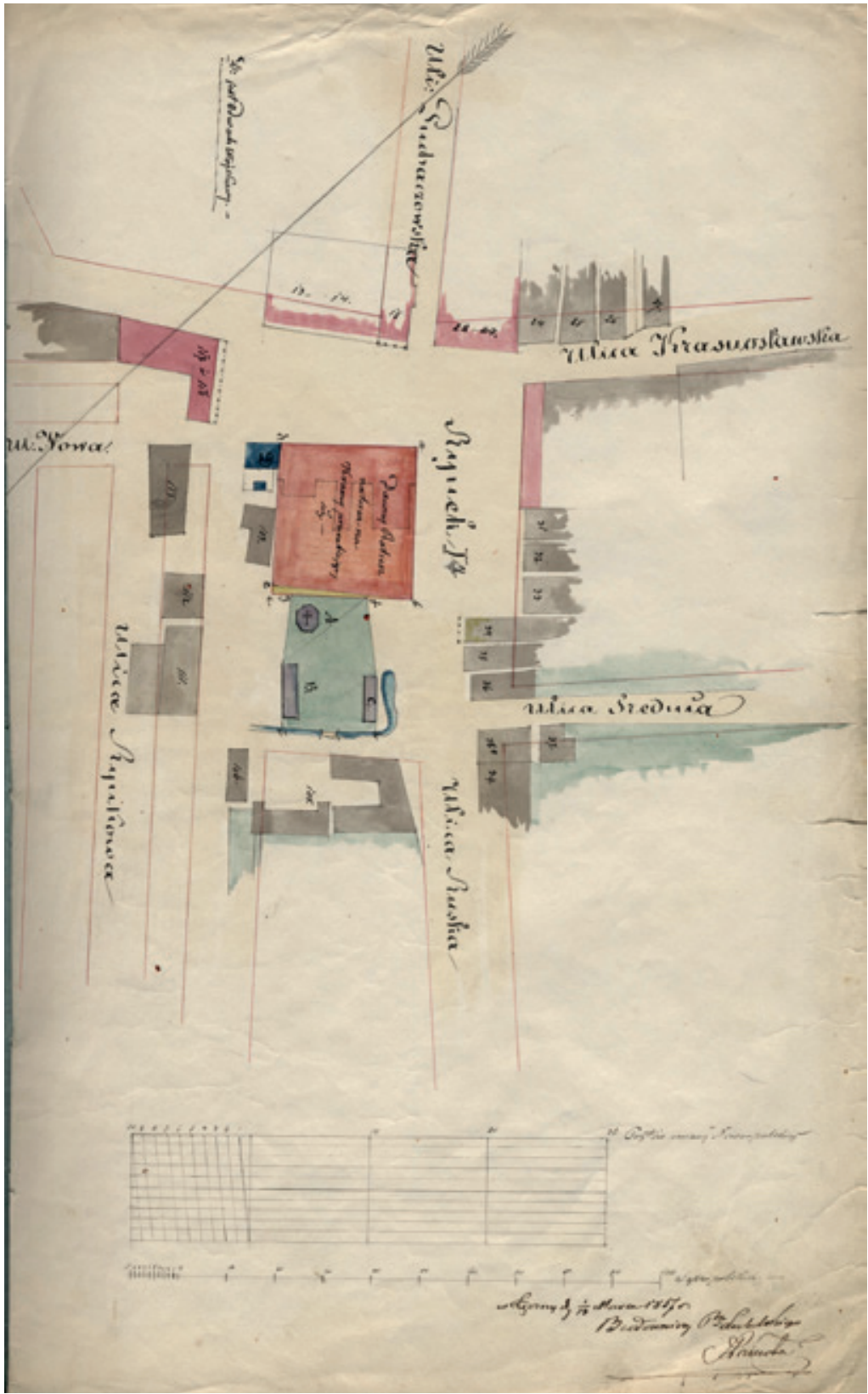

Il. 4. Fragment Rynku I w Łęcznej z zaznaczonym na zielono placem po nieistniejącym już kościele szpitalnym Świętego Ducha i zabudowaniami prepozytury (lit. A, B, C), 1857 r. 


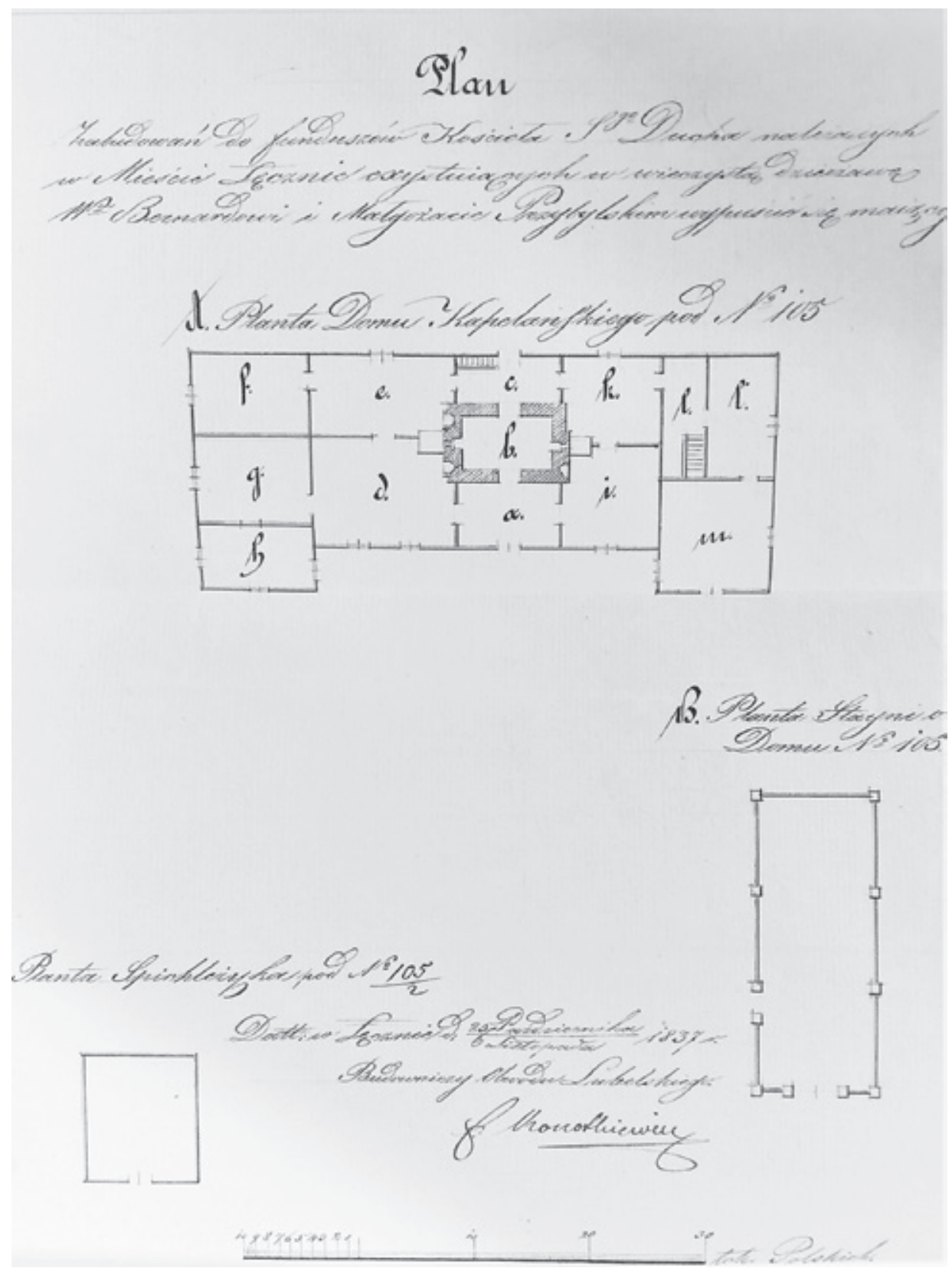

Il. 5. Plan domu prepozyta kościoła szpitalnego pw. Świętego Ducha w Łęcznej, 1837 r. 


\section{Tekst źródłowy}

Or.: Archiwum Państwowe w Lublinie, Komisja Województwa Lubelskiego i Rząd Gubernialny Lubelski, Wydział Administracyjny, sygn. 265, Acta specyjalia tyczące się Łęczny, kościoła i szpitala, k. 81-86v.

Wyd.: R. Jop, Kościót i szpital Świętego Ducha w Łęcznej w wizytacjach $z$ XVIII i XIX wieku, „Merkuriusz Łęczyński”, nr 23, 2010, s. 7-9 (fragment).

[k. 81] Województwo lubelskie, obwód krasnostawski, powiat chełmski. Diecezja lubelska, dekanat chełmski, parafia łęczyńska.

Inwentarz kościoła i funduszu szpitalnego Świętego Ducha w mieście dziedzicznym Łęcznie po śmierci śp. X. Brzozowskiego ${ }^{1}$, dotychczasowego tegoż kościoła kapelana, przez dziekana i delegowanego z administracyi wobec członków Dozoru Kościelnego, niemniej teraźniejszego administratora rzeczonego beneficjum W.J.X. Maksymiliana Wrześniewskiego łącznie z przybranymi znawcami, z oszacowaniem ubytków i uszkodzeń tego funduszu. Stosownie do Dekretu królewskiego z dnia 25 grudnia 1823/6 stycznia 1824 na gruncie w mieście Łęczny dnia 27 września 1834 r. sporządzony.

[k. 81v] Działający. 1. Schybile ${ }^{3}$, burmistrz miasta Łęczny delegowany z administracyi, 2. X. Dymowski ${ }^{4}$, dziekan foralny chełmski, 3. Szymon Wójcicki, członek Dozoru Kościelnego, 4. Felix Kowalski, członek Dozoru Kościelnego, 5. Paweł Sierpiński, obywatel łęczyński, taksator, 6. Augustyn Nokczyński, obywatel łęczyński, taksator.

\section{[k. 82] Tytuł I. Opisanie kościoła i rzeczy do niego należących.}

1. Kościół. Kościół szpitalny Świętego Ducha w Łęczny z drzewa ciosanego w roku 1705, po spaleniu się pierwiastkowego, z jałmużn wybudowany, zreperowany i powiększony został przez przybudowanie nowej zakrystii i dzwonnicy w roku 1788. Kollacyi dziedziców Łęczny. Kościół ten ręką czasu zniszczony, od kilkunastu lat do odprawiania nabożeństwa niezdatny, wystawiał tylko smutny widok spustoszenia. Dziś po zwaleniu się wieży, od głównych drzwi na zachód będącej, po zniszczeniu dwóch znajdujących się w nim ołtarzy i ambony, po przeniesieniu wszystkich

\footnotetext{
Franciszek Brzozowski, proboszcz łęczyński do 1834 r.

Maksymilian Wrześniewski, proboszcz łęczyński w latach 1828-1856.

Adam Schybille, burmistrz Łęcznej w latach 1832-1839.

Jan Ewangelista Dymowski (1798-1889), prałat i dziekan lubelski.
} 
w nim znajdujących się sprzętów, które jeszcze zupełnemu nie uległy zniszczeniu, do parafialnego kościoła, składa się tylko ze zrębu w połowie przegniłego, w ziemię zapadłego, dachem gontowym w połowie przegniłym, a nad prezbiterium opadłym pokrytego, który to zrąb w roku 1833 przez wojsko na skład komory zajęty został. Wchodząc do zrębu dzwonnicy w części z tarcic ogołoconego, nie masz żadnych drzwi, lecz te bez okucia i zamku leżą w zrębie kościoła. $Z$ dzwonnicy wchodząc do zrębu kościoła są drzwi na zawiasach żelaznych z skoblem, bez zamku, który oderwany, znajduje się w składzie. Chór w połowie zrujnowany, do którego nie masz żadnego wchodu. W podłodze kościelnej niemal w połowie przegniłej brakuje tarcic czterech, w zakrystyi zaś i w dzwonnicy żadnej nie masz podłogi. Okien w zrębie kościelnym znajduje się cztery, w połowie wybite. W zakrystyi, do której drzwi nie masz, okno kratą żelazną opatrzone nie znajduje się wcale.

2. Cmentarz. Cmentarz około tego kościoła z trzech stron w połowie ogrodzony żerdziami, od podwórza zaś temu cmentarzowi przyległego sztachetami zupełnie zniszczonymi, z wchodem bez drzwi, obejmuje prętów kwadratowych 70 .

3. Ołtarze. Ołtarze dwa niegdyś w tym kościele znajdujące się za poruszeniem $\mathrm{w}$ celu przeniesienia ich do parafialnego kościoła $\mathrm{z}$ rozkazu władzy wojskowej w roku 1833, przez starość spróchniałe, zupełnie rozsypane, z dyspozycji śp. X. Brzozowskiego spalone zostały. Znajdują się tylko obrazy na płótnie malowane w tychże ołtarzach będące, jako to: Świętego Ducha i Trójcy Świętej [k. 82v] z wielkiego, zaś ŚŚ. Kajetana i Ignacego z pobocznego ołtarza, które znajdują się w parafialnym kościele.

4. Ambona i ławeczki. Ambona i trzy ławeczek były w tym kościele, lecz te, temuż samemu losowi co i ołtarze w czasie przenoszenia uległy.

\section{Sprzęty i ruchomości kościelne}

\begin{tabular}{l|r|r|r|r|r|c} 
& Sztuk & Oszacowanie & Ubytki & \multicolumn{1}{l}{} \\
\hline & & zł. & gr. & szt. & zł. & gr. \\
\hline & & & & & & \\
a) Srebro & 2 & 112 & & & & \\
1. Kielich z pateną w części wyzłacane & 2 & 16 & & & & \\
2. Na obrazie Świętego Antoniego & & & & & & \\
$\quad$ dwie korony wyzłacane &
\end{tabular}

Uwagi. Krzyż srebrny z pasyjką i relikwiarzami Świętych zabrany został za czasów austryjackich. Wotum zaś małe z obrazu Świętego Antoniego skradzione zostało z kościoła w roku 1780, jak dowodzi inwentarz z roku 1797. 


\begin{tabular}{ll}
\hline & \\
\hline & b) Miedź \\
3. Kociołek z denarkiem żelaznym \\
do święconej wody \\
4. Turybularz
\end{tabular}
na nic nie zdatny
c) Cyna

5. Lichtarz na ołtarze
d) Kompozycyja

6. Dzwonek większy z dzwonicy

7. Dzwonków mniejszych $\mathrm{z}$ dzwonnicy

8. Dzwonków małych do ołtarzy

e) Apparaty kościelne i inne sprzęty

9. Ornat czerwony z słupem złotym jedwabną taśmą obszyty

10. Ornat bladego koloru, jedwabny złotymi kwiatkami przerabiany

11. Ornat zielony, jedwabny kwiatkami obwiedziony

12. Ornat biały, jedwabny

[k. 83]

13. Ornat bladego koloru galonkiem złotym obszyty

14. Ornat jedwabny bladego koloru galonkiem złotym obszyty

15. Ornat jedwabny biały, złotymi kwiatkami przerobiony

16. Ornat czarnego koloru, jedwabny białymi, srebrnymi galonkami obszyty Uwagi. Dany do grobu śp. X. Brzozowskiemu

17. Ornat błękitny z słupem zielonym, srebrnymi obszyty

\begin{tabular}{|c|c|c|c|c|c|}
\hline Sztuk & \multicolumn{2}{|c|}{ Oszacowanie } & \multicolumn{3}{|c|}{ Ubytki } \\
\hline & zł. & gr. & szt. & zł. & gr. \\
\hline 2 & 8 & \multirow{10}{*}{10} & & & \\
\hline 1 & 1 & & & & \\
\hline 4 & 5 & & & & \\
\hline 1 & 120 & & & & \\
\hline 2 & 48 & & & & \\
\hline 3 & 1 & & & & \\
\hline 1 & 72 & & & & \\
\hline 1 & 36 & & & & \\
\hline 1 & 36 & & & & \\
\hline \multirow[t]{2}{*}{1} & 36 & & & & \\
\hline & 496 & 10 & & & \\
\hline Sztuk & \multicolumn{2}{|c|}{ Oszacowanie } & \multicolumn{3}{|c|}{ Ubytki } \\
\hline & zł. & gr. & szt. & zł. & gr. \\
\hline 1 & 28 & & & & \\
\hline 1 & 26 & & & & \\
\hline 1 & 15 & & 1 & 15 & \\
\hline 1 & 10 & & 1 & 10 & \\
\hline
\end{tabular}

5 Trybularz - naczynie liturgiczne do okadzania w czasie obrzędów religijnych. 
18. Antepedium ${ }^{6}$ białego koloru, jedwabne

19. Antepedium różnego koloru

20. $\mathrm{Alb}^{7} \mathrm{z}$ korunkami Uwagi. Jedna dana do grobu X. Brzozowskiemu.

21. Komża

22. Obrusów cienkich płóciennych

23. Obrusów grubych

24. Korporałów ${ }^{8}$

25. Puryfikaterzy ${ }^{9}$

26. Humerałów ${ }^{10}$

Uwagi. Jeden dany do grobu X. Brzozowskiemu.

27. Ręczników

28. Kobierzec do ołtarza, stary, podarty

29. Mszałów starych zdezelowanych

30. Mszalik rekwialny

31. Pasków ordynaryjnych

Uwagi. Jeden dany do grobu X. Brzozowskiemu.

32. Ampułki szklane

33. Szafa do składania sprzętów

34. Szafa stara niezdatna

35. Mensa z szufladkami na ornaty i bieliznę

36. Chorągwi na processą

37. Passyjków na ołtarze

38. Krzyżów większych

39. Obrazów wiszących na ścianie podartych

40. Obraz Najświętszej Maryi Panny do noszenia na prosesyi

41. Pozytywek bez piszczałek

42. Portatyl ${ }^{11}$

Summa ogólna

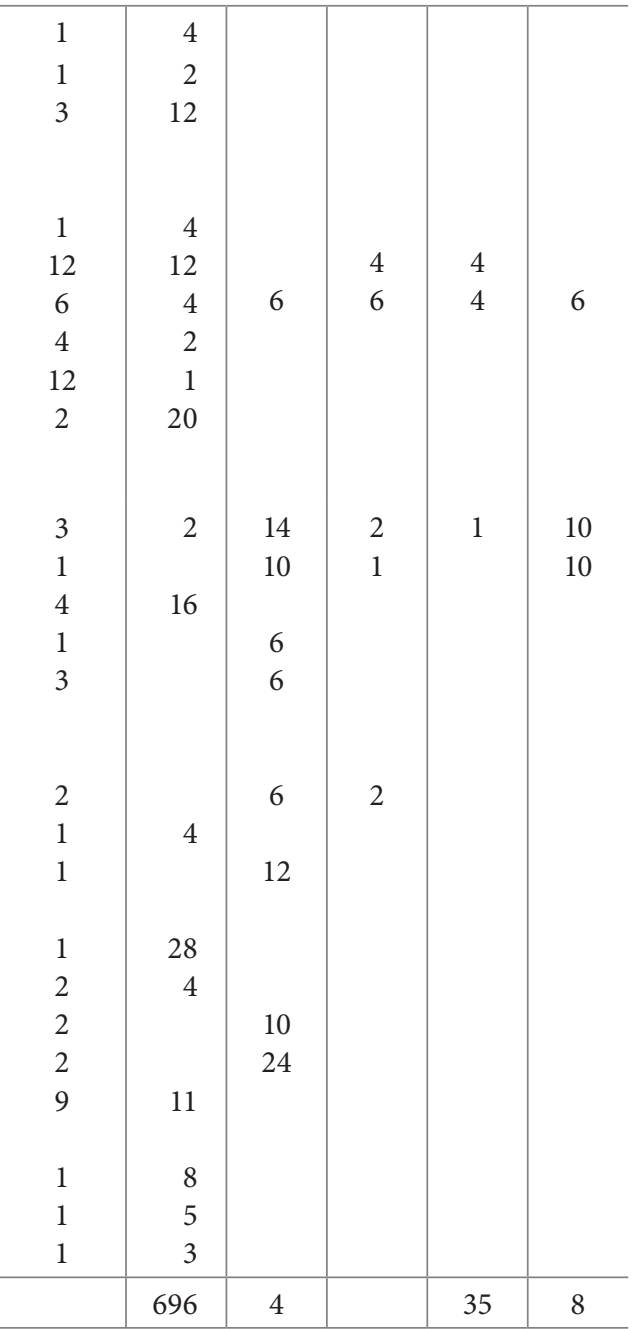

6 Antepedium - bogato zdobione zakrycie lub zasłona mensy ołtarza.

7 Alba-dtuga, biała szata liturgiczna noszona przez duchownych.

8 Korporat - kwadratowy obrus, element bielizny kielichowej, na którym stawia się kielich, patene i cyborium.

9 Puryfikator - w liturgii katolickiej płócienna ściereczka używana do oczyszczania naczyń mszalnych.

${ }^{10}$ Humerał - biała, prostokątna chusta okrywająca szyję i ramiona noszącego albę, element stroju liturgicznego.

${ }^{11}$ Portatyl-mały, przenośny ołtarzyk. 
[k. 83v] Uwaga. Na zapełnienie ubytków w aparatach i sprzętach kościelnych w niniejszym wyrażonych, przyjmuje W.J.X. Wrześniewski administrator całą bibliotekę śp. X. Brzozowskiego, składającą się z książek sztuk 37, które się opisują następnie, z obowiązkiem sprawienia innych albo oddania w czasie tychże książek.

\section{Rejestr książek wyżej wymienionych}

\begin{tabular}{|c|c|c|}
\hline & & Sztuki \\
\hline 1. Kazania księdza Balsama ${ }^{12}$, & tomów & 9 \\
\hline 2. Kazania świąteczne niewiadomego autora, & tom & 1 \\
\hline 3. Kazania tłumaczenia księdza Dunina ${ }^{13}$, & tomów & 2 \\
\hline 4. Kazania Adwentowe księdza Lisikiewicza ${ }^{14}$, & tom & 1 \\
\hline 5. Missja Apostolska, & tom & 1 \\
\hline 6. Kazania księdza Jaśkiewicza ${ }^{15}$, & tom & 1 \\
\hline 7. Kazania księdza Janiszewskiego ${ }^{16}$, & tomów & 4 \\
\hline 8. Kazania księdza Męcińskiego ${ }^{17}$ & tomów & 4 \\
\hline 9. Kazania księdza Żółkiewskiego, & tom & 1 \\
\hline 10. Kazania księdza Karmowskiego ${ }^{18}$, & tom & 1 \\
\hline 11. Nowy głos chwały Świętych Pańskich: przez księdza Goczyńskiego ${ }^{19}$, & tom & 1 \\
\hline 12. Kazania przez księdza Pocieja ${ }^{20}$ & tom & 1 \\
\hline 13. Kazania i naukę, czyli wykład Świętej Ewangelyi, & tom & 1 \\
\hline 14. Wyprawa duszy na tamten świat, & tom & 1 \\
\hline 15. Listy Klemensa XIV & tom & 1 \\
\hline 16. Krótkie zebranie kazań księdza Rydzewskiego ${ }^{22}$, & tom & 1 \\
\hline
\end{tabular}

12 Kasper Balsam (1715-1760), jezuita, kaznodzieja, autor licznych kazań na dni świąteczne.

13 Piotr Stanisław Dunin (1635-1704), jezuita i kaznodzieja.

${ }^{14}$ Franciszek Józef Lisikiewicz (1738-1822), jezuita, fizyk i kaznodzieja; kanonik kolegiaty sandomierskiej.

${ }^{15}$ Mikołaj Jaśkiewicz (1717-1779), poeta i kaznodzieja, kanonik chełmski i łowicki, autor m.in.: „Polityka chrześcijańskiego” oraz „Kazań postnych” (Łowicz 1779).

${ }_{16}$ Antoni Janiszowski (ur. 1728), jezuita, kaznodzieja archikatedry lwowskiej, autor licznych kazań na dni świąteczne.

17 Józef Męciński (1743-1813), franciszkanin, kaznodzieja, autor licznych kazań okolicznościowych i na dni świąteczne.

${ }^{18}$ Kajetan Karmowski (1744-1820), franciszkanin, kaznodzieja, autor kazań okolicznościowych i na dni świąteczne.

19 Właśc. „Nowy głos chwały Świętych Boskich...” Książka Anioła Ignacego Gorzyńskiego wydana $w$ drukarni Jasnej Góry w 1717 r.

${ }^{20}$ Hipacy Pociej (1541-1613), kasztelan brzeski, po wstapieniu do klasztoru prawosławnego biskup włodzimierski i brzeski, greckokatolicki metropolita halicki i kijowski, autor m.in. „Kazań i homilii męża bożego Nieśmiertelnej Sławy...”.

${ }^{21}$ Byćmoże „Listy Klemensa XIV Ganganellego”, wydane w tlumaczeniu polskim w Krakowie w 1778 r.

22 Wawrzyniec Rydzewski (1717-1765), jezuita, kaznodzieja, doktor teologii, autor licznych kazań okolicznościowych i na dni świąteczne. 
17. Archaeologia Polonica,

18. „Memoriale vitae sacerdotalis”23,

\begin{tabular}{l|l} 
tom & 1 \\
tom & 1 \\
tom & 1 \\
tom & 1 \\
tom & 1 \\
tom & 1
\end{tabular}

19. Annus Apostolicus,

20. „Przyjaciel w ostatniej potrzebie doznany”,

21. Scientia iuris fori controversi,

22. „Theologia moralis” Bouzembaum ${ }^{24}$,

\title{
Tytuł II. Spis inwentarza co do rzeczy doczesnych
}

\author{
a) Budynki ${ }^{\mathrm{a}}$
}

[k. 84] 1. Dom kapelana pod numerem 105. Przy ulicy zwanej Pańska jest rezydencyja kapelana w roku 1800 z drzewa wystawiona, $\mathrm{z}$ kominem murowanym porysowanym i z tego powodu zawaleniem się grożącym. Wchodząc z dziedzińca pod wystawą bez filarów, do sieni są drzwi na zawiasach żelaznych z skoblami i haczykiem. Po prawej stronie w sieni wchodzi się drzwiami opatrzonymi klamką do izby czeladnej, w której po prawej jest okno jedno na dziedziniec nikczemnie okute z okiennicą i przechodnikiem. Po lewej jest kominek kapiasty z piecem piekarskim. $\mathrm{Z}$ tej izby idąc $\mathrm{w}$ lewą są drzwi z zawiasami i haczykiem do alkierza, w którym kominek kapiasty i jedno okno małoszybne w połowie potłuczone, bez okucia, z okiennicą i przechodnikiem. Obydwie te izby wspólny piec ceglany ogrzewa. $Z$ alkierza udawszy się w prawą są drzwi opatrzone skoblem do komórki z okienkiem ślepym, opatrzonym haczykiem, w której jest wchód do lochu zdezelowanego. Z tej znowu idąc wprost wchodzi się drzwiami opatrzonymi skoblem do drugiej komórki, w której okno całkiem wybite założone jest okiennicą podnoszoną. $Z$ tej drugiej komórki w prawą są drzwi $\mathrm{z}$ haczykiem do narożnika, w którym okiennica tylko z przechodnikiem. $Z$ tego wchodzi się drzwiami opatrzonymi zamkiem popsutym i skoblem na dziedziniec. W tych wszystkich izbach, komórkach i narożnikach znajdują się pułapy $\mathrm{z}$ tarcic, podłogi żadnej. Wróciwszy się z dziedzińca do sieni po lewej są drzwi z klamką i haczykiem do pokoju, w którym okien dwa na dziedziniec z okuciem, w szyby $1 / 4$ taflowe $z$ okiennicami i przechodnikami. $Z$ tego pokoju po prawej są

a Zestawienie w formie tabelarycznej.

${ }^{23}$ Jedno $z$ wydań "Memoriale vitae sacerdotalis a sacerdote Gallicano" wydrukowano w oficynie trynitarzy lubelskich $w 1801 \mathrm{r}$.

24 „Podręcznik teologii moralnej”. Być może chodzi o rozszerzona wersje „Theologia moralis” Hermanna Busembauma, opracowana przez belgijskiego jezuitę Piotra Lacroix. 
drzwi podwójne z zamkiem francuskim zepsutym i ryglem do drugiego pokoju, w którym jedno okno z okuciem, okiennicą i przechodnikiem, nieco potłuczone. W obydwóch tych pokojach znajdują się kominki i piec wspólny ceglany do grzania. W drugim pokoju idąc w lewą są drzwi z skoblem i haczykiem do zimnego pokoju, w którym jedno okno drobnoszybne, potłuczone $\mathrm{z}$ okiennicą i przechodnikiem. Również z pierwszego pokoju są drzwi podwójne z zamkiem popsutym do podobnego zimnego pokoju, w którym okno w połowie potłuczone. $Z$ tego znowu pokoju idą drzwi z skoblem do pokoju narożnego, w którym okien dwa, w części potłuczonych, z okuciem i okiennicami, z których jedna bez przechodnika. W tych wszystkich pokojach jest podłoga i pułap z tarcic. W sieni tego domu wprost idąc są drzwi z haczykiem do kuchni pod kominem będącej, z tej wychód bez drzwi do tylnej sionki, z tej znowu po prawej drzwi z klamką i haczykiem do alkierza, po lewej takież drzwi do pokoju. W środku zaś drzwi z skoblem na ogród sąsiedzki. Cały ten dom w ziemię zapadły potrzebuje podważenia, dachu nowego, komina $[k .84 v]$ nowego i znacznej w innych częściach reperacji. Oszacowany w Towarzystwie Ogniowym $1900 \mathrm{zł}^{\mathrm{a}}$

Wchodząc na dziedziniec tego domu jest brama bez drzwi, a obok której sztachety zupełnie zniszczone. Po prawej stronie jest stajnia drewniana $\mathrm{z}$ dwojgiem drzwiami pojedynczymi, z których jedna ze skoblem. Zabezpieczona jest w Towarzystwie Ogniowym $200 \mathrm{zł}$.

Po lewej jest drewutnia, czyli szopa drewniana zupełnie zrujnowana. Zamieszczona w Towarzystwie Ogniowym 100 zł.

Obydwa te budynki do upadku nachylone są w stanie zupełnego zniszczenia we wszystkich swoich częściach.

2. Oficyna. Naprzeciwko tego domu, za drogą jest brama z furtką uboczną, obok których sztachety zupełnie zniszczone. Wszedłszy na podwórek po lewej jest dom drugi drewniany z kominem murowanym. Wchodząc do sieni są drzwi z skoblem i haczykiem. Po lewej są drzwi z zamkiem francuskim, antabą, skoblem i haczykiem do pokoju, w którym kominek kapiasty i piec kaflany biały. Okien dwoje z nikczemnym okuciem w części potłuczonych, z okiennicami i przechodnikami. Przez ten pokój idąc wprost są drzwi do drugiego pokoju, gdzie małe okienko z prętem żelaznym, bez okucia. $Z$ tego idą drzwi do komórki, w której okienko ślepe, we wszystkich jest podłoga $\mathrm{z}$ tarcic. Po prawej stronie są drzwi z klamką i skoblem do izby czeladnej, w której kominek z piecem

a Wszystkie kwoty zabezpieczenia budynków odnotowane w osobnej kolumnie tabeli. 
chlebowym i piecem do ogrzania kaflanym, zupełnie zniszczonym. Okien dwoje okuciem miernym w połowie wybite, $\mathrm{z}$ okiennicami i przechodnikami. Przez tę izbę idąc prosto są drzwi z skoblem do spiżarni, w której okno w części wytłuczone z okiennicą i przechodnikiem. W środku sieni są drzwi do kuchni i z tej na przestrzał drugie drzwi na ulicę, obydwoje ze skoblami. Dach tego domu gontem pobity, w połowie przegniły, wymaga nowego pokrycia a cały dom znacznej reperacyi. Zabezpieczony w Towarzystwie Ogniowym $1175 \mathrm{zł}$.

3. Stajnia. Naprzeciwko tego domu jest stajnia drewniana, do której podwoje jedne $\mathrm{z}$ boku, drugie z tyłu z skoblami. W tej są cztery żłoby i komórka na sieczkę. Obok tej stajni pod jednym dachem są dwa chlewiki z drzwiami bez zamknięcia. Cały ten budynek do upadku nachylony. $Z$ jednej strony niedawno gontami pobity, reszta dachu zupełnie opadła. Zapewniony w Towarzystwie Ogniowym $300 \mathrm{zł}$.

4. Stodoły. Przy ulicy Ruskiej wśród miasta na ogrodzie były stodoły, lecz te w roku 1828 w powszechnym miasta pożarze ogniem spłonęły.

5. Szpichlerz. Na tymże ogrodzie jest spichlerz drewniany z wystawą bez filarów, do którego drzwi bez żadnego zamknięcia. W tym podłoga $\mathrm{z}$ tarcic 6 , zasieków zrujnowanych i góra, na którą wschody prowadzą. Cała ta budowla potrzebuje reperacji w podwalinach i dachu nowego. Zapewnione w Towarzystwie Ogniowym 150 zł.

[k. 85] b) Grunta szpitalne, ogrody i łąki

\begin{tabular}{l|c|r} 
& \multicolumn{2}{|c}{ Rozległość } \\
\hline & Morgi & Pręty \\
\hline 1. Pole za pastwiskiem miejskim & 3 & \\
2. Pole od rowu Popowym zwanego & 6 & \\
3. Pole od Gór przy podstawiu & 28 & 150 \\
4. Pole Ćwierć zwane & 16 & 50 \\
5. Pole od Gór do łąki szpitalnej & 23 & 100 \\
6. Ogród przy domu kapelana & 1 & 90 \\
7. Ogród przy ulicy Ruskiej, gdzie spichlerz & 6 & \\
8. Łąka od pola szpitalnego do granicy łańcuchowskiej & 2 & 30 \\
9. Łąka przy łące należącej do parafialnego kościoła & & 76 \\
10. Łąka pomiędzy łąką proboszcza i mieszczanina Pawelca & & 80 \\
11. Łąka przy miejkich łąkach & & 100 \\
12. Łąka za miejską drogą do Ciechanek25 idącą po prawej stronie & &
\end{tabular}

${ }^{25}$ Ciechanki-wieś w par. Łęczna. 
c) Inwentarz żywy

\begin{tabular}{l|c|c|c|c}
\multicolumn{2}{l|}{} & \multicolumn{2}{c}{ Oszacowanie } \\
\hline & $\begin{array}{c}\text { Powinno } \\
\text { być }\end{array}$ & Brakuje & zł. & gr \\
\hline 1. Wołów starych & 2 & 2 & 100 & \\
2. Krów & 3 & 3 & 90 &
\end{tabular}

d) Inwentarz nieżywy

\begin{tabular}{l|c|c|r|r}
\multicolumn{2}{c|}{} & \multicolumn{2}{c}{ Oszacowanie } \\
\hline & $\begin{array}{c}\text { Powinno } \\
\text { być }\end{array}$ & Brakuje & zł. & gr \\
\hline 3. Wozów nie kowanych & 2 & 1 & 15 & \\
4. Soch ze wszystkimi rekwizytami & 2 & 1 & 5 & \\
5. Brona z żelaznymi zębami & 1 & & & \\
6. Skrzynka do sieczki z zerzakiem & 1 & & & \\
7. Kosa do trawy & 1 & & & 15 \\
8. Ćwierć & 1 & 1 & & 6 \\
9. Miarka & 1 & 1 & & 21
\end{tabular}

[k. 85v] Zasiewy gruntowe

\begin{tabular}{|c|c|c|c|c|c|c|c|c|}
\hline & \multicolumn{2}{|c|}{ Ilość } & \multicolumn{2}{|c|}{ Oszacowanie } & \multicolumn{2}{|c|}{ Braki } & \multicolumn{2}{|c|}{ Oszacowanie } \\
\hline & korce & garnce & zł. & gr. & korce & garnce & z1. & gr \\
\hline 1. Pszenicy & 4 & & 48 & & 4 & & 48 & \\
\hline 2. Żyta & 15 & 8 & 152 & & 15 & 8 & 152 & \\
\hline 3. Jęczmienia & 4 & & 32 & 15 & 4 & & 32 & 15 \\
\hline 4. Owsa & 10 & 16 & 42 & & 10 & & 42 & \\
\hline 5. Grochu & & 8 & 3 & & 8 & & 3 & \\
\hline 6. Hreczki & 5 & 8 & 42 & & 5 & 8 & 42 & \\
\hline 7. Konopi & & 8 & 3 & & & 8 & 3 & \\
\hline Summa ogólna & & & 322 & 15 & & & 322 & 15 \\
\hline
\end{tabular}

Uwaga. Konsygnacyją ubytków po oszacowaniu ich dołączył dziekan do inwentacyi z wnioskiem, aby z mszy zmarłego śp. X. Brzozowskiego zapełnione zostały. Również wniósł, aby dezolacyja budowli Świętoduskiego kościoła z massy tegoż zmarłego wynagrodzona została. 


\section{Dochód roczny kościoła Świętego Ducha w Łęczny z krescencyi}

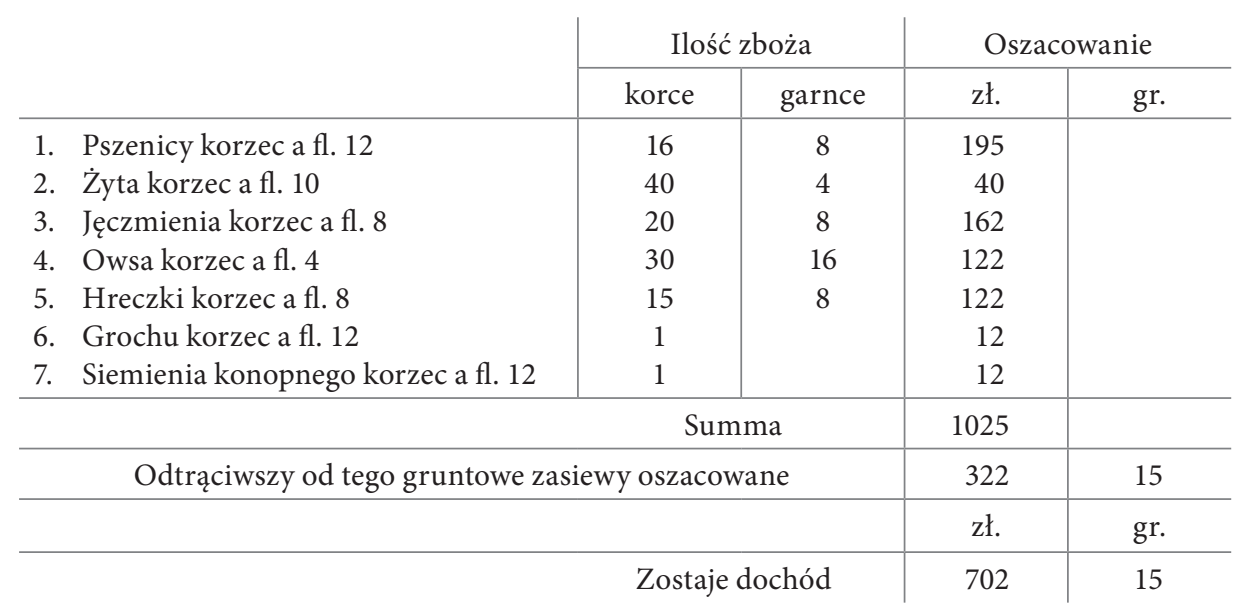

[k. 86] b) Z procentów

\begin{tabular}{l|r|r}
\multicolumn{1}{c|}{ Z przeniesienia strony } & 702 & 15 \\
\hline 1. Od sum w jedną kapitalną połączonych & 172 & \\
w banku złożony złp. 4300, 4/100 & 40 & \\
2. Od summy kapitalnej w banku złożonej 1000, 4/100 & 10 & \\
3. Od summy na Krzesimowie złp. 200, 5/1000 & 924 & 15
\end{tabular}

\section{Rozchód roczny kościoła Świętego Ducha w Łęczny}

\begin{tabular}{l|c}
\multicolumn{1}{c|}{ Z przeniesienia strony } & 702 \\
\hline 1. Podatku podymnego ze wszystkich domów szpitalnych & 24 \\
2. Podatku liwerunkowego z gruntów szpitalnych & 72 \\
3. Podatku subsidi charitativi & 10 \\
4. Podatku szarwarkowego, jak przekonywają kwity & 10 \\
5. Podatku ogniowego z domów kościoła & 42 \\
6. Parobkom dwóm & 250 \\
7. Gospodyni & 100 \\
8. Służącej & 72 \\
9. Na reparacyją budynków & 44 \\
10. Na wosk do mszy funduszowych 156 & 18 \\
\hline
\end{tabular}


11. Na wino do tychże mszy świętych

12. Ubogim

Summa rozchodu

708

Billans

\begin{tabular}{r|c|} 
Przychód czyni & 924 \\
Rozchód czyni & 708 \\
Zostaje na utrzymanie kapelana & 216
\end{tabular}

15

\section{Dokumenta kościoła szpitalnego w Łęczny}

Rok

1540 Anna Spiczyńska półłanek pola kościołowi szpitalnemu w Łęczny zapisuje.

1612 Jakub Bielecki summę 1300 złp. na dobrach Zezulin ${ }^{26}$ i Ziółków ${ }^{27}$ kościołowi szpitalnemu w Łęczny rezygnuje.

[k. 86v] Dokumenta kościoła szpitalnego w Łęczny

Rok

1614 Powyższą fundacyją przez Piotra Tylickiego ${ }^{28}$, biskupa krakowskiego aprobujący dekret.

1619 Piotr Jurkiewicz i jego żona Barbara półłanek pola kościołowi szpitalnemu w Łęczny zapisuje.

1650 Marcin Suchodolski zapisuje kościołowi szpitalnemu w Łęcznie summę złp. 1000.

1739 Assekuracyja na dobrach Łęczny summy złp. 500 przez Seweryna Rzewuskiego $^{29}$.

1751 Stanisław Czernichowski zapisuje kościołowi szpitalnemu w Łęczny złp. 200 na części Ciechanek.

1623 Chryzostom Tur zapisuje testamentem kościołowi szpitalnemu Świętego Ducha w Łęczny łąkę zwaną Pisarzewska.

Rewersa $z$ różnych lat na summy szpitalne dane na prowizyje mieszkańcom Łęczyńskim.

\footnotetext{
${ }^{26}$ Zezulin-wieś w par. Kijany.

${ }^{27}$ Ziółków - wieś w par. Kijany.

${ }^{28}$ Piotr Tylicki (1543-1616), biskup krakowski w latach 1607-1616.

${ }^{29}$ Seweryn Józef Rzewuski (zm. 1754), wojewoda wołyński, podczaszy wielki koronny, właściciel Łęcznej.
} 
Wizyta jeneralna $\mathrm{z}$ roku 1780 .

Takaż wizyta z roku 1800.

Takaż wizyta z roku 1805.

Podobnaż wizyta z roku 1830.

Uwaga. Po przejrzeniu kwitów podatkowych pokazało się, że nie masz żadnej zaległości podatków publicznych, jedynie tylko nieopłacone jeszcze liwerunek i podymne raty drugiej roku bieżącego, których to podatków z massy zmarłego śp. X Brzozowskiego W. J. X. administrator zwrot sobie zastrzega.

Niniejszy inwentarz $\mathrm{w}$ trzech jednobrzmiących exemplarzach sporządzony, podpisany został.

X. Dymowski, dziekan foralny chełmski M.P.

Burmistrz Miasta Łęczny, Schybik M.P.

Wójt Gminy Łęczny Onufry Popiel M.P.

Feliks Kowalski

Szymon Wójcicki

Xiądz Maxymilian Wrześniewski, proboszcz łęczyński, administrator Świętego Ducha.

\section{Bibliografia}

\section{Literatura}

Bogusz M., Miasto Łęczna w czasach Królestwa Polskiego (1815-1866), Łęczna 2014.

Chachaj J., Szpitale przy świątyniach łacińskich $w$ Łęcznej w okresie przedrozbiorowym, „Merkuriusz Łęczyński”, nr 22, 2009, s. 2-8.

Frazik J. T., Łęczna. Rozwój i przemiany planistyczne miasta, „Zeszyty Naukowe Politechniki Krakowskiej", nr 1: Architektura, 1956, s. 47-67.

Góralski Z., Szpitale na Lubelszczyźnie w okresie przedrozbiorowym, Warszawa 1982.

Góralski, Szpitale na Lubelszczyźnie w okresie przedrozbiorowym, cz. II, oprac. D. Wójcik-Góralska, Lublin 1999.

Ihnatowicz I., Projekt instrukcji wydawniczej dla źródeł historycznych XIX i początku XX wieku, „Studia Źródłoznawcze”, t. 7, 1962, s. 99-124.

Jop R., Kościół i szpital Świętego Ducha w Łęcznej w wizytacjach $z$ XVIII i XIX wieku, „Merkuriusz Łęczyński”, nr 23, 2010, s. 4-9. 
Jop R., Zmiany w przestrzeni miejsc sakralnych $w$ Łęcznej $w$ XVI-XVIII wiekukościót św. Marii Magdaleny i Świętego Ducha, [w:] Studia $z$ dziejów parafii pw. św. Marii Magdaleny w Łęcznej, red. R. Jop, Łęczna 2010, s. 89-100.

Jop R., „Jarmark w Łęcznej” Jana Piotra Norblina a łęczyński kościół pw. Świętego Ducha, [w:] Scientia nihil est quam veritas imago. Studia ofiarowane Profesorowi Ryszardowi Szczygłowi w siedemdziesięciolecie urodzin, red. A. Sochacka, P. Jusiak, Lublin 2014, s. 1153-1165.

Łosowski J., Urzędnicy miejscy, cechowi, braccy i szpitalni Łęcznej do roku 1810, Łęczna 2004.

Moskal T., Biblioteka parafialna w Łęcznej w okresie przedrozbiorowym, [w:] Studia $z$ dziejów parafii pw. św. Marii Magdaleny w Łęcznej, red. R. Jop, Łęczna 2010, s. 115-120.

Szczygieł R., Powstanie miasta Łęcznej i jego rozwój do końca XVI w., [w:] Łęczna. Studia z dziejów miasta, red. E. Horoch, Łęczna 1989, s. 31-53.

Tkaczyk J., Zaskakujace odkrycia archeologiczne pod Rynkiem I w Łęcznej - badania wykopaliskowe cmentarza świętoduskiego, „Merkuriusz Łęczyński”, nr 26, 2013, s. 2-8.

Winiarski P., Prepozytura Świętego Ducha w Łęcznej, „Merkuriusz Łęczyński”, nr 17, 2004, s. 9-12. 